\title{
TYING ARRANGEMENTS AND RECIPROCITY: AN ECONOMIC ANALYSIS
}

\author{
JAMES M. Ferguson*
}

Presumably the antitrust laws concern economic problems relating to competition. But the solutions of these problems by the courts are not arrived at on economic grounds but rather are approached in terms of broad social policy, perhaps influenced by a prejudice in favor of preserving small enterprise. According to Neale, the purpose of antitrust is to provide legal checks to restrain economic power, not to pursue economic efficiency as such. ${ }^{1}$ Neale finds that there is a strong judicial tradition in American antitrust which questions the competence of judges to weigh economic arguments and denies that any case-by-case evaluation of the public interest in light of such arguments is required by the law. "The American judges have had good reason for their view that the confrontation of economic experts on both sides of the case would not lead to clear and easily applicable decisions." ${ }^{2}$ He finds it doubtful that economists agree on a body of doctrine on which policy may be based. The concepts of competition and of a competitive economic system are so broad that they offer wide latitude for differences of opinion concerning the proper application of the antitrust laws. The current writer suggests that the core of the problem is that economic argument is being used for normative purposes-to indicate in each case how social policy should proceed. Thus the dispute is not on the level of economic theory but on the plane of applied ethics, and agreement on the theory would still leave unsettled problems as to both the content and the implementation of social policy.

This paper presents an economic analysis of two practices-tying and reciprocity. In a tying agreement, the seller agrees to sell one product to a buyer only if the buyer also agrees to purchase another product from the seller. In a reciprocal buying agreement, the buyer agrees to purchase one product from the seller provided the seller of that product agrees to purchase another product from the buyer. The effects of tying and reciprocity on the competitive structure and performance of a particular industry will depend on many more economic factors than can usefully be considered by the courts in making decisions in concrete cases. Accordingly, an attempt will be made to specify the fundamental market conditions necessary to make these practices effective so as to illuminate the factors most pertinent to

- A.B. I958, Stanford University; Ph.D. I962, University of Chicago. Associate Professor of Economics, University of Virginia.

A preliminary version of this paper was delivered at a student-faculty seminar conducted by the Department of Economics, University of Virginia. Constructive suggestions were offered by the audience, especially Professor G. Warren Nutter.

${ }^{2}$ Alan D. Neale, The Antrtrust Laws of the United States of America 487 (1960).

2Id. at 500 . 
antitrust policy. On the basis of the analysis a few modest policy proposals will be offered which might increase the effectiveness of the enforcement of the antitrust laws.

The first main conclusion of the paper is that tying arrangements depend on horizontal market power in the market for the tying good. Tie-ins allow this market power to be utilized more effectively, increasing the net return from the exercise of that power. Tying arrangements imposed by firms without monopoly power involve benefits to both parties to the tying contract, suggesting that the legitimate aims served by such tie-ins can be achieved without the use of a formal tying arrangement. A per se prohibition against tying is advocated to limit monopoly income; the costs of voiding tie-ins serving legitimate interests would appear to be slight.

Exactly opposite conclusions are reached concerning the treatment of reciprocity. Reciprocity does not depend on horizontal market power and occurs quite often where neither firm possesses such power. In fact, a firm with market power in a factor market would be more likely to use it directly to obtain lower input prices than to exert it indirectly via reciprocity. As a result, it is argued that no attempt should be made to regulate reciprocity under the antitrust laws.

\section{Tying Arrangements}

\section{A. Economic Aspects}

It will be useful to distinguish a number of practices, all of which belong to the family of exclusive practices:

I. Exclusive dealing contracts-one firm obtains the product of another on the condition that it will not deal in the products of third parties; sometimes the buyer or distributor who enters such an agreement receives in return the exclusive right to handle the seller's product in a given market, the result being a bilateral exclusive agreement.

2. Requirements contracts-users or distributors of the firm's product agree to secure from the firm their total requirements for the product over a given period.

3. Tying contracts-buyers or distributors of the firm's product are able to obtain it only on the condition that they also obtain from the firm one or more other products usually used in conjunction with the tying good.

4. Full-line forcing-buyers or distributors of the firm's product are able to obtain it only on the condition that they also obtain the firm's entire line of other products, most of which are not generally used with the tying good.

5. Block booking-movie exhibitors are not permitted to buy films separately but only in combinations specified by the seller.

We are directly concerned only with tying arrangements, but much of what is said is applicable to the other types of exclusive practices. There appears to be 
some justification for separating the first two practices from the latter three in that the buyer or distributor might voluntarily request contracts of the first two varieties. Contracts of the other three types require horizontal market power on the part of the seller, and the degree of coercion is likely to be greater in these cases. If a requirements contract specifies the price of the commodity to be maintained over the period of the contract, the user may thereby shift the risk of price increases to the seller (at some cost, to be sure). If in fact prices of the good offered by other firms fall below the contract price, the user will have an incentive to chisel on the agreement. Thus coercion and policing are by no means absent from these first two kinds of contracts.

The central question in any economic analysis of selling practices is the alternatives open to the parties involved. The cost of any decision is the alternatives that are sacrificed when the decision is made. This is called the opportunity cost. In imposing a tying agreement on buyers, a seller sacrifices the revenue that he could have made by using alternative pricing schemes. Thus he will tend to do so only if he expects greater revenue than under any alternative available to him. Similarly, the buyer will not accept the tie-in unless he considers it superior to the other courses of action open to him. He will not accept the tie-in if he will be better off not using the tying good at all. A seller of wheat cannot force a buyer of wheat also to buy automobiles from him as a condition of purchasing the wheat. The seller must possess horizontal monopoly power in the market for the tying good before he can coerce the buyer into accepting an agreement that he would not accept voluntarily. ${ }^{3}$

Tying arrangements involve several common characteristics. Fundamentally, tieins are used where there is horizontal market power in the market for the tying good combined with inability to manipulate directly the price of the tying good alone, often due to lack of knowledge of individual demands and excessive costs of dividing the users of the tying good into separate groups for purposes of price discrimination. Tying arrangements utilize the market power already possessed more effectively -in a way that increases the net return from the exercise of that power. The central feature of the price adjustments with the tie-in is that the price of the tying good is lowered and the prices of the tied goods are raised compared to the pattern of prices in the absence of the tying arrangement. This result occurs because, almost without exception, firms with horizontal market power will lose revenue on sales of the tying good if they impose coercive restrictions on their customers. "Such firms would lose revenue because they cannot both obtain the advantage of the original power and impose additional coercive restrictions so as to increase their monopoly power." ${ }^{.4}$ The following analysis explains how imposing

\footnotetext{
${ }^{8}$ Subsequent discussion will establish that in tying cases where the tying firm has no monopoly power, buyers should accept the tying arrangement voluntarily. It would appear that tying is not necessary in such cases.

'Director \& Levi, Law and the Future: Trade Regulation, 51 Nw. U.L. REv. 281, 290 (1956).
} 
a compulsory tie-in can increase the net income of a firm with monopoly power over the tying good.

If the firm has a monopoly on one product, it may be able to use a tying arrangement to discriminate among the users of the monopoly good-to charge different prices to different customers that are not proportional to differences in costs. If successful, the tie-in will increase the firm's net return on the monopoly good over and above what it could earn by charging a single price for the tying good alone. To discriminate the firm will select goods that are complementary to the tying good in the sense that they are generally used in conjunction with it. For example, a seller of data processing machines might require that the punch cards employed by the machines also be purchased from him. ${ }^{b}$ The essential characteristic of the relationship between the tying and the tied goods is that different customers use different amounts of the tied good with the tying good. The amount of use of the tied good provides a measure of the intensity of demand for the tying good. On the assumption that the tying good is worth more to those customers who use it intensively, the monopolist will lower the price of the tying good and raise the price of the tied good (compared to the single monopoly price of the tying good sold alone and the competitive price of the tied good).

Such arrangements increase the net return on monopoly power already possessed, but there is no accompanying increase in monopoly power. In these cases, the tied good serves as a counting device to measure intensity of demand for the tying good on the basis of the use of the tied good. The purpose of such tying arrangements is to discriminate among the customers using the tying good with the most intensive users paying the greatest amounts to the firm. The maker of data processing machines is not enabled to increase its profits by driving suppliers of punch cards out of business. In fact, if the other producers of cards can make them more cheaply than the firm in question, it will rationally buy the cards from them rather than manufacture them itself. (Evidence that the firm imposing the tying arrangement was buying the tied good from the existing producers rather than making them would strongly suggest that foreclosure was not the purpose of the tie.) In principle, the firm could achieve the same revenue by renting the machine for the same fixed price and attaching a meter to the machine with an additional charge being made according to the volume of cards used. The cards would then be sold competitively as before.

One obvious question is why the firm does not charge different prices for the machine in the first place and not bother with the tied good. The answer requires an analysis of the three basic conditions necessary for the practice of price discrimination: (I) Different buyers must have different elasticities of demand for the product; (2) it must be possible to separate the markets, and (3) the costs of policing

\footnotetext{
"This will be recognized as the fact situation involved in International Business Machs. Corp. v. United States, 298 U.S. I3I (1936).
} 
the markets to avoid resale from the lower-price to the higher-price markets must not be prohibitively expensive.

To charge different prices for the machine without accurate knowledge of the different intensities of demand of the various users would reduce returns if mistakes were made. The uncertainty concerning the various demands is enhanced when the tying good is durable because the price of the machine must include the present value of the expected net receipt stream to the firm from using the machine. The more durable the machine is, the longer is the period to be taken into account and the more difficult the problem of estimating the value of the machine to the customer. In addition, with different prices, the firm must prevent resale by customers receiving the lower prices to customers who are charged higher prices. Both of these problems can be remedied by the tying arrangement. Prices will be uniform to all customers, thus eliminating problems of resale although there will still be the problem of policing customers to see that they do not purchase their punch cards elsewhere at lower prices. The intensity of demand will be accurately measured by the volume of cards used. One might think that a meter attached to the machine would be preferable to the tie-in, since no policing of card purchases would then be necessary, but the firm would have to inspect the meters to avoid tampering and disconnection. The choice of the form of the arrangement thus depends on the relative costs of policing the discrimination.

It would appear that the use of a meter attached to the machine would have an additional advantage as a method of charging a price based on use-namely, that the user of the machine could purchase the materials used with the machine (punch cards, ink, or whatever might lend itself to a tying arrangement) from any available supplier rather than from the firm making the machine. In fact, the buyer would be willing to pay something for this privilege. Alternatively, he would not feel coerced if the machine were simply sold or leased for a lump sum plus so much per unit of service as measured by the meter. As far as I know, there is no case in which this practice has been attacked. With the meter there is no foreclosure of competition in the market for the tied good. If the company could earn more net revenue by using meters instead of cards to measure intensity of use, surely it would follow this policy. One possible explanation for the apparent infrequency of use of meters is that the seller, while collecting the same total revenue as he would have collected under the tying arrangement without the meter, has the additional expense of the meters and policing them. Therefore, it is more efficient for him to use the tying arrangement. But it would appear that in some cases, at least, the meter would more accurately reflect intensity of demand than the volume of tied goods used with the machine. In such cases, using the meter might be the more efficient method of discrimination.

Burstein offers another way of looking at tying arrangements, which is akin to 
but more general than the price discrimination hypothesis. ${ }^{6}$ Burstein's general position is that a monopolist can increase his net return if he is able to impose conditions for the purchase of the monopolized product apart from his control of the price of the monopolized good and that tie-in sales are one of the auxiliary conditions that are a means of achieving profits above and beyond those attainable by manipulation of the price of the tying good; the price discrimination explanation is simply a special case of this general proposition. Tying arrangements are a means of forcing all-or-none conditions of purchase on the customers for the tying good. These arrangements enable the tying monopolist to capture part of the economic surplus that his customers gain from the use of the tying good. ${ }^{7}$ The general theory fits cases in which the tied goods are independent in demand from the tying goods or are complements or substitutes in demand. Again, as in the price discrimination case above, the increased earnings of the monopolist through the tie-ins depends on the presence of constraints in manipulating the price of the tied good alone. It is assumed that in the absence of the tie-in the monopolist is only able to charge a single price to each customer, although the price may be different for each customer. In no case can the monopolist achieve as great a return as he would earn if he could discriminate perfectly among the users of the tying good by imposing a lump-sum fee for the right to purchase the tying good. ${ }^{8}$ It is also noteworthy that in almost all of the cases that Burstein analyzes, the price of the tying good will fall after the tie-in is initiated.

We must clearly distinguish other examples of tie-ins that do not rest on market

${ }^{\circ}$ Burstein, A Theory of Full-Line Forcing, 55 Nw. U.L. REv. 62 (1960), contains additional explanations of tying arrangements that are independent of this approach and independent of the extension-ofmonopoly hypothesis. There is a much more straightforward explanation of the tie-in sale where the tied good is not being sold competitively. If the market price of the tied good is above marginal cost, then the seller of the tying good cannot extract all of the potential retura from the price of the tying good but must share it with the other producers of the tied good. Therefore, the seller of the tying good, who is also a producer of the tied good, will impose the tie-in to keep from sharing the profits from the sale of the final good with the other producers of the tied good. If he has to purchase the tied good from them, because they sell it at a price above their marginal cost but below the cost at which he can produce it, he will have to share the gains with the producers of the tied good. Burstein also argues that considerations of risk and uncertainty provide additional grounds for tying arrangements.

" "Consumer's surplus" may be defined as the excess of what a consumer would be willing to pay for a good rather than do without it over what he actually does pay in a normal market transaction. In the normal market, the consumer can choose to buy at any given price a given quantity indicated by his preferences or some lesser amount. An all-or-none offer requires the consumer to purchase the given quantity or none at all.

${ }^{8}$ Consider the plight of a monopolist selling an intermediate product to processors. The basic consideration is that the ultimate source of revenue for a producer of an intermediate good is the demand conditions for the final good. "[T] he very existence of monopoly power in an intermediate product prevents the monopolist from realizing all of the profit potential inherent in that power, since monopoly pricing of the input will cause distortion of the production technique . . . [at the later stages]." Burstein, stupra note 6, at 80-8I. As a result, at the final goods stage, the firms will be using less of the monopolized input and more of other inputs than would be optimal (than would occur if all inputs were supplied to the final-product firm at a competitive price). An appropriate set of tieins would allow the monopolist to control the input prices of all the factors used at the later stages and increase his returns above the level resulting from control over the single monopolized input. (This case also illustrates the relationships between tying and vertical integration.) 
power for the tying good. Each of these cases is basically different from the monopoly situation because here the interests of the prospective tying firm and the customer-user are not in conflict. Given this condition, it would appear that the same aims could be achieved without the use of compulsory tie-ins.

There appear to be three sets of circumstances in which imposing a compulsory tie-in can increase the net income of a firm having no monopoly power over either good:

I. If there are economies in the production and/or sale of the two items jointly, there may be no loss in making the joint sale compulsory, but there does not appear to be any reason for doing so. The firm should be willing to sell each separately at prices that sum to more than the joint price.

2. If there is a price ceiling or other restriction on price in one market, it can be evaded by requiring the purchaser to buy a nonprice-fixed item. ${ }^{9}$ The consumer may only pay what he is willing to pay for the two items in the absence of the price regulation. Consumers will be better off as a result of this arrangement than they would be in its absence.

3. The manufacturer may merely desire to protect the good will of the principal product by tying the use of his repair parts to the sale of the product. This is the technological interdependence argument for tie-ins. In such cases, the usefulness of the main product depends on the adaptability of some essential complement. "If the essential complement did not conform to exact specifications, it might impair the operation or usefulness of the principal product."10 The use of poor punch cards with the seller's data processor might actually damage the machine. "When the exact source of poor performance is difficult to trace, the supplier will be especially concerned that no foreign elements are being used with his machines."11

The third case, to a greater extent than the other two, may involve imperfectly competitive markets. It is consistent with the other two cases because the interests of the two parties are not in conflict under specified conditions. The justification for requiring the purchase of seller-supplied parts or auxiliary equipment to assure proper functioning of the seller's main product rests on the inferior quality of these goods made by rival suppliers. But if these inferiorities actually existed, buyers would voluntarily purchase their needs from the seller of the basic product; absent such inferiorities, they might prefer to utilize alternative sources. A careful listing of the specifications that must be met by the complements used with the machine might be sufficient in particular cases and would leave the user of the machine free to buy from anyone meeting those requirements.

\footnotetext{
Tying clauses may merely disguise the price of the product for promotional purposes and involve price competition. This may especially important in oligopolistic industries in which direct price reductions may elicit cutthroat competition from rivals.

${ }_{10}$ Bowman, Tying Arrangements and the Leverage Problem, 67 YALE L.J. 19, 28 (1957).

${ }^{11}$ lbid.
} 


\section{B. The Law of Tying Arrangements}

Section 3 of the Clayton $\mathrm{Act}^{12}$ reads as follows:

It shall be unlawful for any person engaged in commerce, in the course of such commerce, to lease or make a sale or contract for sale of goods, wares, merchandise, machinery, supplies, or other commodities, whether patented or unpatented, for use, consumption, or resale within the United States or any Territory thereof or the District of Columbia or any insular possession or other place under the jurisdiction of the United States, or fix a price charged therefor, or discount from, or rebate upon, such price, on the condition, agreement, or understanding that the lessee or purchaser thereof shall not use or deal in the goods, wares, merchandise, machinery, supplies, or other commodities of a competitor or competitors of the lessor or seller, where the effect of such lease, sale, or contract for sale or such condition, agreement, or understanding may be to substantially lessen competition or tend to create a monopoly in any line of commerce.

This is the only specific statutory language prohibiting tie-ins, and even here tying arrangements are not specifically mentioned. Section 3 was held to cover tying contracts because they could be used to achieve the same purpose as exclusive dealing arrangements. ${ }^{13}$ The language covers both patented and unpatented items whether sold or leased, but its coverage is limited to commodities. As a result of this latter limitation, some of the most important tying cases have been brought under section $\mathrm{x}$ of the Sherman Act. ${ }^{14}$

The Supreme Court's position in postwar tying cases can best be presented by quotations from several of the leading cases. First, consider the following from the Times-Picayune case in $1953{ }^{15}$ which concerned the tying of advertising in the only morning newspaper in New Orleans to the sale of advertising in one of two afternoon papers:

With its decision in International Salt Co. v. United States, 332 U.S. 392 (1947), this Court wove the strands of past cases into the law's present pattern. There leases of patented machines for dispensing industrial salt were conditioned on the lessees' purchase of the lessor's salt. A unanimous Court affirmed summary judgment adjudicating the arrangement unlawful under $\S 3$ of the Clayton Act and $\S$ I of the Sherman Act as well. The patents on their face conferred monopolistic, albeit lawful, market control, and the volume of salt affected by the tying practice was not "insignificant or insubstantial." Id. at 396. Clayton Act violation followed as a matter of course from the doctrines evolved in prior "tying" cases. . . . And since the Court deemed it "unreasonable, per se, to foreclose competitors from any substantial market," neither could the tying arrangement survive $\S$ I of the Sherman Act. 332 U.S. at 396 . That principle underpinned the decisions in the Movie cases, holding unlawful the "block-booking" of copyrighted films by lessors, United States v. Paramount Pictures, 334 U.S. 131, 156-59 (1948), as well as a

\footnotetext{
${ }^{12} 38$ Stat. 731 (1914), I5 U.S.C. $\$ 14$ (1958).

${ }^{13}$ United Shne Mach. Corp. v. United States, 258 U.S. 451 (I922).

1426 Stit. $209(1890)$, as amended, 15 U.S.C. \$ I (1958).

18 Times-Picayune Publishing Co. v. United States, 345 U.S. 594, 608-09, 6rx (r953).
} 
buyer's wielding of lawful monopoly power in one market to coerce concessions that handicapped competition facing him in another. United States v. Griffith, 334 U.S. 100, 106-08 (1948). From the "tying" cases a perceptible pattern of illegality emerges: When the seller enjoys a monopolistic position in the market for the "tying" product, or if a substantial volume of commerce in the "tied" product is restrained, a tying arrangement violates the narrower standards expressed in $\S 3$ of the Clayton Act because from either factor the requisite potential lessening of competition is inferred. And because for even a lawful monopolist it is "unreasonable, per se, to foreclose competitors from any substantial market," a tying arrangement is banned by $\S I$ of the Sherman Act whenever both conditions are met.

$\cdots$

But the essence of illegality in tying agreements is the wielding of monopolistic leverage; a seller exploits his dominant position in one market to expand his empire into the next. Solely for testing the strength of that lever, the whole and not part of a relevant market must be assigned controlling weight.

In $195^{8}$ the Court decided the Northern Pacific case, ${ }^{16}$ which involved the validity under the antitrust laws of deed covenants requiring the landowner to use the defendant's freight services, i.e., the tying of freight service to land sold. In overturning the covenants, the Court stated as follows: $:^{17}$

Of course where the seller has no control or dominance over the tying product so that it does not represent an effectual weapon to pressure buyers into taking the tied item any restraint of trade attributable to such tying arrangements would obviously be insignificant at most. As a simple example, if one of a dozen food stores in a community were to refuse to sell flour unless the buyer also took sugar it would hardly tend to restrain competition in sugar if its competitors were ready and able to sell flour by itself.

Again, in the Loew's case, ${ }^{18}$ which involved block booking of movies offered for television exhibition, the Court stated:

This case raises the recurring question of whether specific tying arrangements violate $\S \mathrm{I}$ of the Sherman Act. This Court has recognized that "tying agreements serve hardly any purpose beyond the suppression of competition," Standard Oil Co. of California v. United States, 337 U.S. 293, 305-06 (1949). They are an object of antitrust concern for two reasons-they may force buyers into giving up the purchase of substitutes for the tied product, see Times-Picayune Pub. Co. v. United States, 345 U.S. 594, 605 (I953), and they may destroy the free access of competing suppliers of the tied product to the consuming market, see International Salt Co. v. United States, 332 U.S. 392, 396 (I947). A tie-in contract may have one or both of these undesirable effects when the seller, by virtue of his position in the market for the tying product, has economic leverage sufficient to induce his customers to take the tied product along with the tying item. The standard of illegality is that the seller must have "sufficient economic power with respect to

\footnotetext{
${ }^{16}$ Northern Pac. Ry. v. United States, 356 U.S. I (1958).

${ }^{17}$ Id. at 6-7.

${ }^{18}$ United States v. Loew's, Inc., 37I U.S. $38,44-46$ ( 1962 ).
} 
the tying product to appreciably restrain free competition in the market for the tied product. ..." Northern Pacific R. Co. v. United States, 356 U.S. I, 6 (I958). Market dominance-some power to control price and to exclude competition-is by no means the only test of whether the seller has the requisite economic power. Even absent a showing of market dominance, the crucial economic power may be inferred from the tying product's desirability to consumers or from uniqueness in its attributes.

The requisite economic power is presumed when the tying product is patented or copyrighted, International Salt Co. v. United States, 332 U.S. 392 (I947); United States v. Paramount Pictures, Inc., 334 U.S. I3I (I948).

Finally, we find this statement in two cases not involving tying arrangements: $:^{18}$

Thus, unless the tying device is employed by a small company in an attempt to break into a market, ... the use of a tying device can rarely be harmonized with the strictures of the antitrust laws, which are intended primarily to preserve and stimulate competition.

One commentator's survey of the tying cases concludes as follows: ${ }^{20}$

The legal and economic standards of proof observed in tying arrangement cases are far more flexible than the phrase "per se" suggests. Courts generally inspect the degree of market power in the tying goods, as well as the amount of commerce affected in the tied goods, before passing on whether the tying arrangement tends to lessen competition. In the majority of tying cases the initial facts have indicated, without the need for further investigation, the presence of substantial market power over the tying goods. However, where the defendant does not possess any obvious market power, an examination should be made of the various indicia of economic power held over the tying goods.

Not only is the use of the term "per se" unnecessary for finding whether competition tends to be lessened, but it is misleading in purporting to exclude economic evidence which the courts continue to admit in tying arrangement cases. The unimportance of the phrase was recently demonstrated by Justice Goldberg's omission of "per se" from the entire Loew's opinion.

The misinterpretation of "per se" as a doctrine which excludes virtually all economic evidence is a result of its erroneous treatment as the antithesis of the Rule of Reason. The courts, in purported applications of "per se" doctrine, have not only recognized, but admitted into evidence, economic data reflecting an inquiry into the markets for the tied and tying goods. Consequently, the phrase "per se" should either be totally dispensed with in the law of tying arrangements, or if retained, employed as an informal procedural guide indicating the quantum of evidence required in a given case.

At the same time this commentator recognizes that tying arrangements between unpatented and patented items are presumed to be illegal. ${ }^{21}$

The recurrent themes of these cases are (I) that tying arrangements extend monopoly power from the tying good market to the tied good market through the

\footnotetext{
${ }^{10}$ White Motor Co. v. United States, 372 U.S. 253,263 (I963), quoting Brown Shoe Co. v. United States, 370 U.S. 294, 330 (1962).

${ }^{30}$ Singer, Market Power and Tying Arrangements, 8 Antrtrust Burl. 653, 667 (1963).

${ }^{21}$ Id. at 66r.
} 
leverage created by the tie-in and (2) that the only purpose of tying arrangements is to restrict competition. Nevertheless, except in patent cases, the courts examine the market conditions and look for evidence of market power. We cite the opinions of the court only to establish that tying arrangements are not per se illegal in the sense that evidence that the arrangement exists is not sufficient to condemn it without showing the presence of some power in the tying good market and a sufficient volume of commerce in the tied good market. This view of the court's position is consistent with those of other writers who have examined these cases. ${ }^{22}$

\section{Conclusions and Policy Suggestions on Tying Arrangements}

The courts try to avoid lengthy discussion of complicated economic issues and prefer to rely on simple criteria, such as evidence of intent to foreclose competitors from the market or the fact that a substantial volume of commerce is involved in the tied good. But the courts, in addition, almost always make some attempt to determine whether the firm imposing the tie-in has market power. They condemn tie-ins in the presence of horizontal market power in the market for the tying good on the ground that tie-ins are a means of wielding monopolistic leverage. Tie-ins create leverage by which the firm extends its monopoly power from the market for the tying good to the market for the tied good, creating monopoly power in new markets. Such an explanation does not appear consistent with the facts in many cases.

Economists who have considered the phenomenon of tie-in sales have almost unanimously agreed that tie-ins serve other purposes than the extension of monopoly from one level to another and the erection of barriers to entry. Suspicions were aroused by an examination of the tying cases in which the tied goods were salt, toilet paper, rivets, staples, and other common products and in which the monopolist's share of the market for the tied good, which had many uses other than with his equipment, was very small.

Furthermore, the arguments that tying increases the barriers to entry appear subject to severe limitations. Most economists writing on tying arrangements recognize that tie-ins can serve to impede entry. The following quotations are examples of opinions that have been expressed:

x. Thus, where there are important economies of scale resulting in large initial capital requirements and where risk is an important element, to close off a substantial segment of downstream markets can seriously discourage potential entrants into the upstream process. ${ }^{23}$

2. In most cases it [the tying clause] will increase the capital investment needed

${ }^{22}$ Singer, supra note 20; Turner, The Validity of Tying Arrangements Under the Antitrust Lauvs, 72 Harv. L. Rev. 50 (1958); Baldwin \& McFarland, Some Observations on "Per Se" and Tying Arrangements, 6 Antitrust Burl. 433 (1961).

${ }^{23}$ Burstein, supra note 6 , at 94 n.80. 
by the potential entrant, as he may have to produce a substitute for the tying product in order to enter the market for the tied product. ${ }^{24}$

In addition, Kaysen and Turner argue,

If the only effects of tie-ins were those of price discrimination, we could not justify our per se ban. But viewed in dynamic terms, tie-ins have effects which go beyond the effects of comparable price discriminations, and lack justifications which price discriminations may have. A tie-in always operates to raise the barriers to entry in the market of the tied good to the level of those in the market for the tying good. ${ }^{25}$

In their view, a newcomer must be able to supply both products since he must displace the entire package offered by the established firm. And they argue that it may be difficult to find a substitute for the tying product. This argument assumes that the potential newcomer cannot enter only at the level of the tied good market because there are no alternative uses for the tied good. Thus, where there are other uses and other buyers outside the tying arrangement, this argument does not hold. Furthermore, where the firm imposing the tie buys the tied good from other producers rather than making it itself, entry at the tying level is not impeded by the tie. When using the tie-in as a discriminatory device, the tying firm will have an incentive to buy the competitive good (the tied item) from the other suppliers if they can make it more cheaply. In such cases, there is no significant foreclosure. Finally, entry by large diversifying firms will not be impeded by the greater capital needed. With an established reputation, borrowing costs may be constant over a wide range. ${ }^{28}$

The economic analysis in this paper, in contrast to that of the Supreme Court, mentioned nothing about intent or foreclosure of competitors but concentrated solely on the alternatives open to the participants in tying arrangements. It was argued that the central feature of tie-ins is use of market power already possessed

"' Baldwin \& MeFarland, Tying Arrangements in Law and Economics, 8 ANrrrroust BulL. 743, 773 (1963).

${ }^{25}$ Carl Kaysen \& Donald F. Turner, Antrtrust Policy 157 (1959).

11 The discussion of barriers to entry in the recent literature and court cases leaves much to be desired. No one bothers to analyze what they mean by entry or what they mean by barriers to entry. A useful distinction can be made between freedom of entry and the cost of entry-which will help to eliminate much of the confusion. Entry is free when the long-run costs of new firms, if they enter, will be equal to those of established firms in the industry. The presence of economies of scale in firm sizes in a particular industry means that the average cost of producing per unit of output decreases with the scale of operation. If this condition held at all scales of plant, then there would only be one firm in the industry - a case of so-called natural monopoly. The fact that we observe more than one firm in a given industry over time suggests that beyond some seale the average cost per unit of output begins to increase. Where economies of scale are significant relative to the size of the market, a firm that enters the industry may have to invest a large amount of capital in building a plant of minimum efficient size. This by itself indicates no barrier to entry.

Furthermore, the available data indicate that the minimum efficient size of plant is small relative to the size of the market in almost all industries. In most industries there is a range of optimum sizes. Also, entry frequently occurs on a scale that is smaller than the average scale within the industry. It is often possible to enter a regional market rather than entering the whole national market. 
in a way that increases the net return from the exercise of that power. Extension of power into new markets or exclusion of entry is incidental to this rationale. From this point of view, wielding monopolistic leverage means the use of existing monopoly power to discriminate among or impose all-or-none conditions on purchasers of the tying good, thereby increasing the returns on the power already possessed. The fact that in a tying arrangement the price of the tied good is raised above the competitive level or the fact that the firm imposing the tie earns more with the tie-in than without does not indicate that monopoly power has been created in the market for the tied good. (Recall that the price of the tying good will almost always fall after the tie-in is imposed.) Of course, this rationale does not preclude the tying firm from sometimes gaining market power in the market for the tied good, especially where the tied good has no uses except with the tying good. But the legality of the tie-in can be determined on the basis of the market share of the firm in the tying good market without need to consider in addition its market share of the tied good or the effects of the tie-in on entry.

Suppose that the explanation for tie-ins in the presence of monopoly power over the tying good is use of market power already possessed to increase the net return on that power. Does more effective use of monopoly power already possessed warrant different policy conclusions than creation of additional market power through use of tie-ins? A negative answer can be justified. The existing per se rule is beneficial because "it limits the potential gains from monopoly power."

Do the legitimate ends served by tie-ins make it impossible to justify a per se prohibition? The foregoing economic analysis has also shown that tying arrangements in the absence of monopoly power can serve legitimate ends. But it was also shown that all but one of these ends can be achieved in the absence of tying. Where there are cost savings in joint production and sale, offering lower prices for both goods will attract sales. Similarly, it will be rational for the buyers of the tying good to use seller-supplied auxiliary goods without the tie-in, provided these goods are actually better than those of rival firms. The only case in which a per se prohibition on tying might cause damage occurs where there is some restraint on price in the market for the tying good that can be avoided through tying. The author doubts that this case occurs very often.

The current writer finds the courts' per se approach to be acceptable, although based on incorrect economic reasoning. Since the per se rule does not remove the need for evidence in addition to the performance of the tie-in, it is useful to specify what the court should consider. It has been argued that the court need not consider the market share of the tied good foreclosed to competitors, nor the effects of tie-ins on potential entrants, nor even that legitimate ends can be served by tie-ins not based on market power. The primary factor in tying cases is the presence of monopoly power in the market for the tying good. Without this dominant market

${ }^{37}$ Burstein, supra note 6 , at 93 . 
position, the firm cannot successfully coerce users of the tying good to purchase the tied good from it.

A simple procedure in these cases would be to determine the market share in the tying good market and prohibit all tie-ins where the market share of the tying firm is above some figure such as fifteen per cent. ${ }^{28}$ (This rule is not as arbitrary as it might appear, since the definition of the market is somewhat elastic. Also, the rule might designate that the acceptable share vary inversely with the dollar volume of sales in the market.) Such a procedure will not eliminate all auxiliary means of increasing the net return on monopoly power; certain price differentials may be employed in the absence of formal tie-ins to achieve the same aim. ${ }^{29}$ Finally, the

\footnotetext{
${ }^{28}$ If the main rationale for the patent system is to allow the individual to appropriate the fruits of his research, which he could not otherwise do, then it appears to this writer that this reason may also constitute grounds for the legality of noncollusive patent tie-ins. One of the reasons why tie-ins often occur in patent cases is that the holder of the patent has very limited monopoly power to collect a return on his patent in the absence of auxiliary mechanisms such as tying. This consideration is especially important in the combination patent cases in which the inventor devises a new way to combine existing products.

One of the clearest statements of the problem of applying the Clayton Act to tie-ins in combination patent cases is given by Justuce Jackson in his dissent in the Mercoid case. His views also express the opinion of the Court on the basic issue:
}

"Here the patent covers a combination-a system-a sequence-which is said to be new, although every element and factor in it is old and unpatentable. Thus we have an abstract right in an abstruse relationship between things in which individually there is no right-a legal concept which either is very profound or almost unintelligible, I cannot be quite sure which.

.....

"Of course the abstract right to the 'sequence' has little economic importance unless its monopoly comprehends not only the arrangement but some, at least, of its components. If the patentee may not exclude competitors from making and vending strategic unpatented elements such as the thermostat, adapted to use in the combination, the patented system is so vulnerable to competition as to be almost worthless. On the other hand, if he may prohibit such competition, his system patent gathers up into its monopoly devices long known to the art and hence not themselves subject to any patent.

.....

"The practical issue is whether we will leave such a combination patent with little value indeed or whether we will give it value by projecting its economic effects to elements not by themselves a part of its legal monopoly. In these circumstances I think we should protect the patent owner in the enjoyment of just what he has been granted-an abstract right in an abstruse combination-worth whatever such a totality may be worth. I see no constitutional or statutory authority for giving it additional value by bringing into its monopoly all or any of the unpatentable parts."

Mercoid Corp. v. Mid-Continent Inv. Co., 320 U.S. 66I, 678-80 (1944).

As this case involves fixed proportions with a given number of thermostats being used with each furnace unit and the thermostat involved in the tie-in was designed for use only with the patented system, it would appear dubious that any extension of monopoly power is involved. In fact, Mercoid, the owner of the patent on the process, did not even make the thermostats but entered into an agreement with a thermostat manufacturer. In effect Mercoid received royalties on its patent based on the number of its furnace systems installed as measured by the use of these specially designed thermostats. It would be consistent with the purpose of the patent laws to uphold the tic-ins in such cases, as they provide the only means of collecting the return on the legal patent. Perhaps Mercoid should have offered to make the same contracts with all thermostat manufacturers, as then noncompliance on the part of the latter would be even stronger evidence of intent to circumvent the patent.

${ }^{30}$ Unfortunately, even with a per se rule the practice might persist. The problem of policy must also cover the question of whether the illegal purposes of the tying arrangement can be achieved in the absence of the tie-in. Kaysen and Turner treat this as a problem of identification of the arrangement:

"Another kind of difficulty of identification can arise where there is no explicit prohibitory agree- 
courts may be well advised to pay more attention to the legitimacy of the horizontal market power that permits coercive tying and to consider possible means of removing such market concentration.

\section{II}

\section{ReCIPROCITY}

\section{A. Economic Aspects}

The essence of a reciprocal buying arrangement has been variously stated. The following quotations are examples:

$\mathrm{x}$. The essence of the arrangement is the willingness of each company to buy from the other, conditioned upon the expectation that the other company will make reciprocal purchases. The goods bought are typically dissimilar in kind, and in the usual case could be obtained from other sources on terms which, aside from the reciprocal purchases, would be no less advantageous. Where such a relationship is well established, it prevents the competitors of each company from selling to the other company, and affords to each company whatever increase of size and strength can be derived from an assured place as supplier to the other ${ }^{30}$

2. "Business reciprocity" . . . describes business dealings between independent firms whereby they make mutual concessions designed to promote the business interests of each....

The best-known form of business reciprocity is reciprocal buying. Reciprocal buying involves the use by a firm of its buying power to promotes its sales. ... . Reciprocal buying is economically significant when a firm can make sales in this way that it could not otherwise make or could make only at greater costs. Reciprocal buying is essentially a selling technique in markets of imperfect competition. ${ }^{31}$

3. But it is the power of reciprocal buying to increase a firm's sales that is most significant to industrial structure. A large diversified firm, by integrating its buying and selling, may shift its demand function to the right and thereby grow..$^{32}$

4. Reciprocal dealing is both the use of purchasing power to obtain sales and the practice of preferring one's customers in purchasing. A regular sales tool of many of America's large corporations, the practice is often systematic, noncontractual, and carefully designed to avoid transgressing the uncertain limits of the law..$^{33}$

ment which enforces the tie, but only a large price difference between the tied and the separate purchases. ... No hard and fast rule can be laid down; where the price differences are sufficiently great, the arrangement can be identified as a tie-in; . . . if not, then the only problem that arises is one of price discrimination."

RAYSEN \& TURNER, op. cit. supra note 25 , at 154 . This in effect suggests a rule of reason in identifying the practice. But if the practice can be performed without formal agreement, the court must then decide which price differences are legitimate and which are not, for which task it is ill-equipped, as the Robinson-Patman cases have amply demonstrated.

${ }^{30}$ Edwards, Conglomerate Bigness as a Source of Power, in National Bureat of Economic REsearch, Business Concentration and Price Policy 331, 342 (1955).

${ }^{31}$ Stocking \& Mueller, Business Reciprocity and the Size of Furms, 30 J. Bus. 73, 74-75 (1957).

${ }^{2}$ Id. at 94 .

${ }^{88}$ Hausman, Reciprocal Dealing and the Antitrust Laws, 77 Hanv. L. REv. 873 (1964). 
Secondary reciprocal relations occur "where a supplier requests business from a company because he buys from one of its major customers." tions:

Reciprocal purchasing agreements may arise under a variety of factual condi-

x. A firm may threaten to withdraw its patronage if the other company does not reciprocate in its buying.

2. There may be an agreement whereby each company agrees to buy from the other.

3. Possibly there are only suggestions by one company that simple justice requires that the other should buy from the first in view of the first company's purchases from it.

4. Finally, one company might merely elect to purchase from a potential customer for its products because of the possibility, and in the hope, that the other company will reciprocate. ${ }^{35}$

These situations embrace a wide range of behavior under the title of reciprocity. Tacit reciprocity (item 4 above) does not even involve mutual purchases but only purchases by one firm on the basis of hopes that the other will reciprocate. We will ignore such cases as being irrelevant or at least beyond the scope of a realistic antitrust policy and will consider only cases $\mathrm{I}-3$ from the list.

Most of the definitions quoted above do not adequately describe the practice of reciprocity because they say nothing about the prices at which these transactions occur. (Selling costs and other aspects of the transaction are also relevant.) Are the prices higher than those quoted by alternative sources or are they equal or are they less? Cases in which firms buy from each other at the lowest available prices because each is an efficient producer simply involve sound business practice. Each will willingly buy from the other at these prices, and no monopoly power is needed. It will be argued that a buyer with market power in the input market will prefer to use his purchasing power directly to coerce suppliers to sell at lower prices rather than indirectly to coerce suppliers to buy his products at prices above those available from other firms. Only if he is constrained not to use his purchasing power directly will he resort to reciprocity. There remains the case in which a mutual agreement or understanding is reached whereby both suppliers will buy from the other at prices equal to those available elsewhere; this is probably the most common variety of reciprocity arrangement.

We define reciprocity as the bilateral practice in which the buyer agrees to purchase from the seller and the seller agrees to purchase from the buyer at specified prices. As reciprocity allegedly is confined mainly to producers of intermediate

\footnotetext{
st Id. at 878 .

${ }^{35}$ The enumeration is based on Harsha, The Conglomerate Merger and Reciprocity-Condemned by Conjecture, 9 ANTmRust BuLd. 201, 208 (1964).
} 
goods and seldom occurs among producers of final products, the discussion will be limited to concerns of the former variety. ${ }^{36}$ Consideration of the alternatives . open to the two parties will permit evaluation of the practice of reciprocity and reveal its limitations.

Three different sets of market conditions facing two representative industrial firms will be examined in the numbered sections that follow to determine which market characteristics are most conducive to the practice of reciprocal buying. Assume that product $\mathrm{X}$ is used by firms that make product $\mathrm{Y}$ and vice versa. Firm $A$ is a representative of the $X$ industry, and Firm $B$ is a representative of the $Y$ industry. (It is not necessary that $Y$ be used in making $X$ or vice versa, as these may be multiproduct firms. Reciprocal agreements may also involve more than one product, and firms in other industries may also use either product.) The determinant of Firm A's purchasing power is the share of the total output of $Y$ purchased by it, not its share of the total sales of $X$ nor its share of the sales of $X$ to Firm B.

\section{r. Many Firms in Both Industries}

Where neither industry is characterized by concentration, it is obvious that neither party can impose on the other reciprocal agreements in which any firm is forced to purchase inputs at prices higher than those available from other sources. Each firm has numerous alternative suppliers and will not voluntarily sacrifice the opportunity to purchase from others at lower prices without receiving significant consideration. Reciprocity under these conditions will simply involve business practices in accord with legitimate profit motives.

Alternative sellers are especially important given the dispersion of sellers' asking prices, which "is ubiquitous even for homogeneous goods."37 Prices change with varying frequency in all markets, and a buyer will hardly know all the alternative prices at any moment in time. As a result, it will pay any buyer to invest time and effort in securing market information on alternative asking prices for the goods that he needs to purchase. For any buyer the expected savings from an additional unit of search will be greater the greater the dispersion of prices and the greater his expenditure on the commodity. (Another important determinant of the amount of search will be the correlation of asking prices by sellers in successive periodsthe degree to which the sellers who quote the lowest prices in one period also do so in later periods. With changes in the identity of both buyers and sellers over time in any market, price dispersion will continue, and it will be rational for the individual participant in the market to continue to engage in search.)

\footnotetext{
${ }^{36}$ One might expect that producers of consumer goods and services (i.e., department stores) might ask their employees to purchase from them. And they customarily do, but they usually also allow them to purchase at discount prices. This type of arrangement the workers will enter into voluntarily. In fact, in department stores the discount privilege is considered part of the worker's compensation.

${ }^{37}$ Stigler, The Economics of Information, 69 J. Pol. Econ. 213 (196r).
} 
If the buyer and the seller each considers the other to be a low-cost firm-one that quotes a relatively low price in the market-then each may be willing to enter into a reciprocal buying arrangement. But even under these favorable conditions, it will probably not pay one or both of them to adhere to the agreement over time as the identity of the sellers offering the best terms changes. Each of the participants in the agreement will have an incentive to raise his selling price to the other relative to the asking prices in the market. As a result, each cannot save the costs of search over time except by paying a higher price for the good in question."

Two additional legitimate interests may be served by reciprocity under the assumed market conditions, namely reduction of uncertainty and reduction in selling costs. To have assured customers for one's products may reduce uncertainty concerning sales for each of the parties to a reciprocal purchasing agreement. This factor does not appear to be impressive, but economic analysis of uncertainty is still in a. relatively primitive stage. In view of the comments made above, it would appear that sales are certain under these contracts only as long as superior alternatives do not appear. The firm does not find itself then in a less rigorous competitive. environment, except that it will make reciprocal sales at competitive prices! If reduction of uncertainty did occur, we would expect other pairs of firms also to enter into these contracts.

Again starting from an initial situation in which neither of the firms is doing business with the other, a reciprocal agreement might reduce the selling costs of both firms entering the agreement. Assuming each remained a customer of the other for some time, costs of selling might be reduced. Again we would expect other pairs of firms to enter into similar arrangements where really justified by cost savings. Reciprocity among the firms in the two markets is an alternative to. forming a joint sales organization in each market to advertise for all the firms rather than having the individual firms do so. In the latter case, the total advertising by the firms in each industry, under reasonable assumptions, will exceed the industry advertising profit maximum. In other words, reciprocity may reduce the costs of competition in each industry. Again the savings in selling costs to the firm will tend to be confined to cases in which selling prices remain equal to (or lower than) those available from other firms. While the current writer is unable to assess the importance of each of the above-mentioned factors, as well as others not mentioned here, these conditions do represent legitimate purposes of reciprocity agreements in the absence of any coercion.

In all of these cases, neither firm is initially doing business with the other. Why not also include cases in which Firm $A$ is buying $Y$ from Firm $B$, but the latter is not buying $X$ from the former? Presumably Firm A chose to buy from Firm $B$ because $B$ offered terms equal to or better than those available from other firms making $Y$. Presumably Firm B chose not to purchase $X$ from $A$ because $A$ did not offer the best available terms. A request from $A$ asking $B$ to purchase $X$ from 
A because $A$ purchases $Y$ from $B$ will not be sufficient to induce $B$ to do so. For Firm $B$ to change would involve costs to him that he will not voluntarily incur. Firm $A$ will also have to match the terms offered by other sellers of $X$ in order to sell to Firm B, just as he would have to do if he were not buying from B. A firm without market power may ask his suppliers to purchase from him; such reciprocity constitutes a sales promotion device and should be treated as such. If the firm offers to sell at prices equal to those available elsewhere, his suppliers might be willing to buy from him as long as these price conditions persist. Without market power, the firm will not be able to induce suppliers to purchase from him at prices higher than those available elsewhere (account also being taken of other dimensions of sale, including quality and service).

In the absence of market power, reciprocity, at best, can secure sales for the firm at equal prices. Competitors are foreclosed from sales at equal prices, but this fact is of little consequence since all firms can practice reciprocity; there will be many such agreements among mutual suppliers. In the absence of power to enforce the agreement in the presence of lower prices offered by other sellers, these agreements will not lessen competition and therefore are not a proper concern of the antitrust enforcement agencies.

\section{One or a Few Buyers and Many Sellers}

Next we consider situations in which there are one or a few firms producing $X$ and many firms producing $Y$ or vice versa. Recall that firms in each market buy from and sell to firms in the other market. Of course, reciprocity may occur at equal prices for the same business reasons outlined in the previous section. Are there any other circumstances in which reciprocity will occur at prices other than those quoted by other firms under these market conditions?

Consider the alternatives open to a buyer. If the supplier-seller is earning only a competitive rate of return, then the buyer cannot impose additional costs on him. Requiring sellers to purchase some product from the buyer at a price higher than they would have to pay elsewhere will only drive the supplier-seller out of business, a result that is not in the interests of the buyer. Only if the suppliers are earning extra-normal income can the buyer hope to gain anything from the practice of reciprocity. If the last is the case, presumably the buyer can use his dominant market position in the supplier's market to secure a low price on the goods purchased, which will tend to eliminate the extra-normal income being earned at an earlier stage in the production process. If the buyer lacks the power to achieve this result through the purchase price of the supplied goods, how can he possibly impose a higher selling price on the goods used by the supplier? Certainly if there were only one buyer, he would use his purchasing power directly and not use reciprocity.

One plausible condition in which reciprocity makes sense when there are few buyers and many sellers is in the presence of constraints on price cutting in the 
market for the buyers' products. The presence of restraints appears to offer a feasible explanation of the reciprocity cases of the $193^{\circ}$ 's involving railroads. ${ }^{38}$ Given a public utility that is not allowed to discriminate in prices by granting lower prices to large shippers, the utility will have an incentive to employ auxiliary means of cutting prices to large shippers having the best alternatives in transport. Buying railroad equipment from firms owned by these large shippers at prices above those available elsewhere is a means of giving these customers rebates and avoiding the regulations on the pricing of utility services. (The higher costs may lead to slightly higher rates on railroad services, but these will be paid by all customers, not just the favored ones.) Within limits it would appear that such arrangements would be mutually beneficial. Note that it is the few buyers of railroad equipment who are paying higher prices for their equipment than they would have to pay from other equipment manufacturers. They do so in order to give indirect rebates to the large shippers or buyers of railroad services, who are also in this case sellers of railroad equipment. The few buyers of railroad equipment do not coerce their suppliers to buy railroad services at higher prices. The large buyers of railroad services are also not coercing the railroads to buy from their equipment firm. As other equipment manufacturers were available, it is obvious that the railroads voluntarily entered the agreement to secure business that might otherwise have gone to other types of transport.

Could not this argument also be applied to oligopolistic industries with few firms in which direct price competition is not used because price reductions are promptly matched? An oligopolist will seek ways to increase his sales that cannot be promptly matched by rivals. Entering into reciprocity arrangements with suppliers who also use the oligopolist's products may achieve this aim. The thrust of the argument is that the oligopolist will pay higher prices on the items purchased from his suppliers as a means of giving rebates on sales to his suppliers. Presumably these rebates will be less easily discovered by other oligopolists than direct price cutting. Such a condition may exist in a growing market, but it appears to be of limited empirical validity. (Suppliers may be subject to antitrust prosecution for selling to the oligopolist at prices above those at which they sell to other firms, but the oligopolist will not be the one who brings the complaint.)

The essential feature of both the public utility and oligopoly examples is that a firm with market power combined with restrictions on price cutting uses reciprocity as a means of selling at a discount. The firm with market power in the selling market does not coerce its suppliers to buy from him because it buys from them. Suppliers are able to buy from the dominant firm at prices below those quoted to other buyers.

\footnotetext{
${ }^{38}$ See Mechanical Mfg. Co., I6 F.T.C. 67 (1932); Waugh Equip. Co., I5 F.T.C. 232 (1931). This explanation of the railroad cases is given by Hale \& Hale, Reciprocity Under the Antitrust Laws, II3 U. PA. L. REv. 69, 70 ( 1964$)$.
} 
In conclusion, no rationale has been developed to support coercive reciprocity (in which the buyer forces suppliers to purchase goods from him at prices above those available from other sources) when there are one or a few buyers and many sellers. ${ }^{30}$ A single buyer will use his purchasing power directly to obtain the intermediate good at competitive prices. Several buyers who also sell the same products may use reciprocity as a means of cutting prices that cannot be so easily matched by rivals. ${ }^{40}$

\section{One or a Few Buyers and One or a Few Sellers}

The situation where the markets for both products $\mathrm{X}$ and $\mathrm{Y}$ are concentrated presents the most interesting case and the one that might appear most important in analyzing the practice of reciprocity. This is the situation that Corwin Edwards - regards as dangerous: "Between two powerful concerns, however, reciprocal buying may be a device by which each supports and helps consolidate the strength of the other, so that independent producers of both commodities are deprived of market opportunities."

The basic flaw in this argument appears at once when this simple question is asked: Would a supplier with monopolistic control of a resource input used at a Iater stage :make more money by having the market at that later stage competitive - or monopolistic? The answer is, of course, that he would make more money by having the next stage competitive. (Excluded from consideration is distribution of sproducts that require many services to accompany them either in the sale or servicing of the product, as such conditions are not relevant to the reciprocity dis: cussion.) Similarly, the seller has an incentive to foster competition in the factor markets as this means lower costs of production for him and, with given demand . for his product, higher net income. There is a clear conflict of interest. For given 1. demand conditions, higher profits to the supplier mean lower profits to the buyer. $\because$ 'The supplier can charge the buyer a price that makes the buyer's cost of production just less than they would be without using the input sold by the monopolistic supplier or just less than the cost to the buyer of obtaining the input from other . sellers or by integrating backward to the supplier's level. Similarly, the buyer

\footnotetext{
${ }^{30}$ When there are only a few buyers of an intermediate product who are oligopolistic sellers and other buyers who sell in competitive industries, it may be more profitable for the few (large) buyers to use reciprocity rather than to use their purchasing power to secure lower prices from the suppliers of the intermediate product. If the large buyers exert their purchasing power directly to obtain lower prices on the intermediate product, suppliers will continue to sell at higher prices to the smaller buyers and be subject to antitrust prosecution on grounds of price discrimination. To avoid the antitrust problem and still increase their net returns, the large buyers may resort to reciprocity to increase sales of their products (at prices above the competitive level). It would appear that this case would occur very seldom, especially since with many suppliers, any supplier selling to a large buyer may not be selling to any small buyers, in which case there would be no price discrimination.

10 To further complicate the issue, a cartel might choose to assign each buyer of the cartcl's products to a particular firm as one means of attempting to enforce the cartel pricing policies. The cartel member would then be unable to cut prices to attract additional customers. Each cartel member might be assigned customers who are his suppliers.

${ }^{2}$ Corwin D. Edwards, Maintaining Competition 179 (I949).
} 
cannot make the supplier pay more for his needs than the cost to him of doing without the product made by the firm at the later stage or the cost to the supplier of buying from other sellers or of integrating forward to make the good himself and sell to the next stage. The threat of withdrawal of purchases by the buyer will not impress the supplier since the buyer will have to incur costs of finding alternative sources of supply just as the supplier will have to locate a new customer or go into production at the later stage himself.

Assume the income of both parties is above the competitive level due to the monopoly power that each possesses in his market. Why each will believe that the monopolistic position of the other will help to maintain his own monopoly position is not clear. Furthermore, even if they consent to a reciprocal purchasing agreement, each will have an incentive to chisel and buy from alternative sources at lower prices. To reinforce each other's position requires that potential entrants at the buyer's level, for example, will be unable to obtain the necessary intermediate goods from the monopolistic supplier. But it is in the interest of the supplier with monopoly power to foster competition at the next level, as this will increase his return from his monopoly control of the input. Also he might be able to purchase his inputs at lower prices with more firms in the other market. Foreclosure of markets at one level will tend to dampen expectations of successful entry at the other level only if the potential entrant does not realize that if he does enter at one level, the monopolist at the other level will have an economic incentive to buy from and sell to him, either lowering the monopolist's costs or increasing his sales or both. ${ }^{42}$ The result of entry will be an increase in net revenue to the firm(s) at the level where entry does not occur. This condition gives each of the dominant firms an incentive to break a reciprocal agreement.

What mechanism exists for enforcing reciprocity agreements in these cases? What means can be developed to make the costs of breaking the agreement exceed the gains? Furthermore, in how many actual situations will the two firms be using each other's products in the same volumes?

\section{Conclusions}

The main conclusion of this economic analysis is that coercive reciprocity in which the buyer coerces his suppliers to buy from him at prices higher than those quoted by other firms has no foundation in economic theory. Reciprocal buying will occur among firms without market power at competitive prices. Reciprocal buying at prices equal to those available from other sellers will also occur when firms possess market power. There does not appear to be any mechanism con-

\footnotetext{
${ }^{2}$ It may be that, because of dominance in either market, entry will not occur, but this is due to horizontal market power. In such cases, entry may be accomplished, even in the absence of the reciprocity agreement, only by a large diversifying firm that will not face limitations in the capital market that increase the cost per unit of capital to enter at both levels.
} 
nected with such an agreement that will enhance the market power of either firm. When there is one or a few buyers, they will use their purchasing power directly to obtain lower prices of the intermediate goods that they use. Finally, reciprocity may be used as an indirect means of price cutting on sales to suppliers, when there are contraints on price cutting in the market for the buyers' products. None of these cases appear to offer any targets for the guns of antitrust. If this is the case, an examination of antitrust cases involving reciprocity is likely to reveal deficient economic reasoning to support the view of an antitrust violation.

\section{B. The Law of Reciprocity}

We will examine a recently decided conglomerate merger case dealing with reciprocity to determine any circumstances in which the practice will be successful. The respondent in this Federal Trade Commission proceeding was Consolidated Foods Corporation, a large wholesaler and retailer of foods. In r951, Consolidated acquired Gentry, a firm that produced dehydrated onion and garlic, which products were used by some of Consolidated's suppliers in making seasoned foods that they sold to Consolidated. The FTC ${ }^{43}$ and ultimately the Supreme Court ${ }^{44}$ held that this merger violated section 7 of the Clayton Act. ${ }^{45}$

It is indeed necessary to commend the FTC for its originality in discovering another abuse supposedly created by product diversification. To condemn conglomerate mergers among firms in different markets as violations of the amended section 7 requires ingenuity since the firms share no common demand or supply curves and there is no immediate effect on competition-no increase in concentration, no decrease in the number of independent firms, and no foreclosure of competitors from sales to the acquired firm. To attack these mergers the FTC attempts to demonstrate that there has been an increase in the market power of the merging firms that will produce the necessary anticompetitive effect at some later date. Absolute size is the alleged villain, although absolute size is not easily equated with either market power or market control. The charge in Consolidated Foods was that the acquiring firm's financial strength-here purchasing power-would probably enable Consolidated to increase the acquired firm's market share at the expense of other producers selling in the acquired firm's market. Firms from which Consolidated made heavy purchases were allegedly put under pressure to buy Gentry's products, and in some instances they agreed to do so notwithstanding their objections to the quality of Gentry's products as compared with products of its competitors.

The FTC's position was that a diversified firm is in a much better position to practice reciprocal buying than a single-line firm and that greater diversification

\footnotetext{
${ }^{48}$ Consolidated Foods Corp., Trade Reg. Rep. (Transfer Binder, 196r-63) I I6182 (FTC 1962).

" FTC v. Consolidated Foods Corp., 380 U.S. 592 (1965), reversing 329 F.2d 623 (7th Cir. 1964).

${ }^{45} 8$ Stat. 73 I (I914), as amended, I5 U.S.C. $\$$ I8 (1958).
} 
gives more opportunities to engage in reciprocity. ${ }^{46}$ Consolidated thus allegedly had the power to defeat other firms in the acquired firm's market on the strength of its buying power in other markets rather than on the basis of a better product or lower price. The Commission thus found a clear connection between the merger and the probability of injury to competition. The mere connection with Consolidated and its huge purchasing power, said the FTC, would give Gentry an unfair competitive advantage, increasing its sales without any action on its part; Consolidated's suppliers who used products of the type made by Gentry would voluntarily switch to buying from Gentry to stimulate favor with Consolidated! Competitors in the market of the acquired firm would thus be foreclosed from part of their market. The defense relied solely on the argument that the Government had failed to present evidence that showed probability of effect sufficient to cause a substantial lessening of competition in the market for Gentry's products.

What was the change in Gentry's market share after the merger? Here the Court had substantial evidence, since the merger took place in $195^{\mathrm{I}}$ and was not challenged until I962. Most of the market data started before the merger and continued through 1958. Let us examine the market shares in the two relevant markets-dehydrated onion and garlic. The market share data for the four companies that sold dehydrated onion and garlic in the years $194^{8-195^{8}}$ are shown in the following tables: ${ }^{47}$

Dehydrated Onion Market Shares

\begin{tabular}{lllcc}
\hline \hline Year & Basic & Gentry & Puccinelli & Simplot \\
\hline 1948 & $62 \%$ & $24 \%$ & $3 \%$ & II\% \\
1949 & 55 & 31 & 9 & 5 \\
1950 & 60 & 28 & 7 & 5 \\
1951 & 59 & 27 & 5 & 9 \\
1952 & 59 & 27 & 8 & 6 \\
1953 & 52 & 36 & 7 & 5 \\
1954 & 66 & 29 & 4 & 1 \\
1955 & 57 & 29 & 8 & - \\
1956 & 58 & 33 & 9 & - \\
1957 & 52 & 38 & 10 & - \\
1958 & 57 & 35 & 8 & \\
\hline
\end{tabular}

\footnotetext{
${ }^{10}$ Diversification increases the number of opportunities for reciprocal buying as well as their magnitude:

"A single-line producer, even though a near-monopolist, may buy so little of some material that reciprocal buying has little infuence on suppliers as potential customers. But by diversifying-making other products requiring the same input-a firm may so enlarge its buying as to give it the power to increase its sales. Practically all of a giant diversified firm's purchases of goods and services may achieve importance as a means of increasing sales."

Stocking \& Mueller, supra note 31 , at 77 .

${ }^{47}$ Brief for Respondent, p. 30, FTC v. Consolidated Foods Corp., 380 U.S. 592 (I965).
} 
Dehydrated Garlic Market Shares

\begin{tabular}{|c|c|c|c|}
\hline Year & Basic & Gentry & Puccinelli \\
\hline I948 & No Data & No Data & No Data \\
\hline I949 & $39 \%$ & $53 \%$ & $8 \%$ \\
\hline 1950 & $3^{6}$ & $5^{I}$ & I3 \\
\hline I95I & $4 I$ & 48 & II \\
\hline I952 & 38 & 50 & I2 \\
\hline I953 & 44 & 47 & 9 \\
\hline I954 & 45 & 46 & 9 \\
\hline 1955 & 46 & 44 & ro \\
\hline $195^{6}$ & 47 & 43 & ro \\
\hline 1957 & 42 & 47 & $x x$ \\
\hline I958 & 50 & 39 & II \\
\hline
\end{tabular}

These data reveal the following:

I. The market for dehydrated onion and garlic was concentrated before Consolidated entered the picture.

2. Over the period from $195^{\circ}$ (the year before the merger) to 1958 Gentry increased its onion market share from twenty-eight per cent to thirty-five per cent, but its garlic market share fell from fifty-one per cent to thirty-nine per cent. No explanation is given by the Government as to why reciprocity should work in the onion market but not in the garlic market. Basic was the leading producer at the beginning of the period and at the end of the period. Combining the two markets, Basic increased its over-all market share more than did Gentry during the period.

3. Perhaps the most interesting finding revealed in the tables is that Puccinelli, a smaller firm, survived and in fact prospered during the period. It had an average onion market share in the 1948-50 period of 6.3 per cent and this increased to an average of 8.8 per cent in the $1955-5^{8}$ period. Its garlic share averaged a little less than eleven per cent in both periods. Why wouldn't a smaller firm feel the brunt of Consolidated's actions? It is true that a fourth firm, Simplot, did leave the onion industry in 1956 .

4. There is a healthy fluctuation in the respective market shares in the onion market. Gentry's increase in 1953 apparently was largely due to underproduction of dehydrators in 1952, and Gentry was the only firm to meet the 1953 market demand by importing dehydrated onion. But in 1954 and 1955 Gentry had a market share one per cent more than in 1950. Why did it take so long for the tacit reciprocity and the overt reciprocity to exert their effects? The increase in Gentry's share after 1955 may be due in large part to product improvement-removal of wood splinters from their product! (There is some question as to the resulting improvement since the large firms did not in most cases substantially increase their purchases 
from Gentry-perhaps there also were increases in price more than sufficient to offset the improvement in quality.)

5. There is no evidence that Consolidated stopped purchasing from suppliers who refused to buy from Gentry. Moreover, there is no evidence that Consolidated ever channeled extra business to those who did buy from Gentry. The absence of evidence here appears to be strong support for the view that Consolidated lacked power to induce suppliers to buy from Gentry on terms less advantageous than those available from other dehydrated onion and garlic makers.

It is difficult to determine simply from evidence of purchases that they occurred because of reciprocity. Most of the FTC's evidence related to large customers of Consolidated, but, as the evidence demonstrates, Consolidated's largest customers purchased relatively less of their total purchases of onion and garlic from Gentry than did its smaller customers. There is no evidence that Consolidated had market power as indicated by a large share of the market for any commodity produced by any supplier. Food distribution is a large industry with many large firms. There is no support for the view that Consolidated had a dominant share in any market conferring on it ability to coerce suppliers to purchase from Gentry.

The success of Puccinelli is even more remarkable in view of the vast increase in demand for dehydrated onion and garlic by the big food companies over the period in response to growth in consumer demand for seasoned foods. Many" of these food buyers decided to protect their source of supply by purchasing from two suppliers. There is no evidence that this desire was due to reciprocal influences. The FTC argued that in choosing a second outlet, these food firms would be induced to pick Gentry. But the market share data reveal that the smallest firm, Puccinelli, increased its market share after the acquisition of Gentry by Consolidated. Gentry increased its share in the onion market primarily at the expense of the leading firm in the market.

What does the defendant's brief have to say about reciprocity when price, service, and quality are equal? This may be the crucial aspect of the case from the FTC's point of view. Admitting that it would be more rational to use purchasing power to lower prices of purchases from suppliers than to increase suppliers' costs by buying from a less efficient enterprise, the FTC could argue that where market concentration is absent and services are equal, the buyer may attempt to persuade suppliers to use Gentry's products at equal prices. Consolidated's brief argues that the dimensions of sale are seldom equal:

As the evidence summarized in the Reciprocity Supplement shows, one or more of price, service and quality factors were continually varying among the onion and garlic suppliers, and there is no reason to believe that this intensely competitive picture will be altered in the future.

Further there is no proven probability that reciprocity will operate even where price, service, and quality are equal.48

\footnotetext{
${ }^{48}$ Id. at p. 58.
} 
This appears to be a weak argument, for surely there is little reason for suppliers not to agree if these factors were equal. The fact that Consolidated tried unsuccessfully to induce suppliers suggests strongly that in fact the cost of buying from Gentry was greater for many food firms.

The Supreme Court reversed the lower court and upheld the Commission in a unanimous decision with two concurring opinions. The Court held that reciprocity was one of the anticompetitive practices at which the antitrust laws were aimed and described reciprocity as " 'an irrelevant and alien factor' ... intruding into the choice among competing products, creating at the least 'a priority on the business at equal prices. "' $\$ 9$ The Court's opinion said that all acquisitions that create the probability of reciprocal buying are not illegal:

Some situations may amount only to de minimis. But where, as here, the acquisition is of a company that commands a substantial share of a market, a finding of probability of reciprocal buying by the Commission, whose expertise the Congress trusts, should be honored, if there is substantial evidence to support it.

The evidence is in our view plainly substantial. Reciprocity was tried over and again and it sometimes worked..$^{50}$

The only substantial point is made in a concurring opinion by Mr. Justice Stewart, who felt that evidence not referred to in the Court's opinion was decisive. Small processors who do not have well known brands and must rely on the wholesaler to encourage their distribution are the ones who can be influenced by reciprocity:

My reading of the record persuades me that most of the processors in this ... class shifted their buying from Basic to Gentry, though the extent of that shift varied from company to company. It is true that testimony from the purchasing agents of many of these companies attributed the shift to other causes. However, the pattern of movement in this class, when contrasted to the lack of a pattern among the major processors, seems to me sufficient to support the Commission's conclusion that these shifts were in response to the influence of reciprocity, whether express or "tacitly accommodative."

The evidence does not reveal that Consolidated had a large market share in any relevant food market, and there is no evidence that Consolidated attempted to use its purchasing power to coerce its suppliers to purchase from Gentry. In the absence of market power, it is not surprising that Consolidated asked its suppliers to purchase from Gentry, as a simple selling technique. Since those suppliers who agreed to buy from Gentry would not voluntarily increase their costs, apparently Gentry was able to supply some suppliers at the same price as was available from other firms. Reciprocity, like advertising, may create a priority on business at equal prices, and competitors charging equal prices may be foreclosed from sales to some suppliers.

\footnotetext{
$193^{80}$ U.S. at 594 .

${ }^{60} I d$. at 600 .

${ }^{61} I d$. at 607 .
} 
But in the absence of market power to enforce the agreement in the presence of lower prices offered by other sellers, these agreements will not lessen competition. In the Consolidated Foods case, there is no evidence that competitors were even harmed.

\section{Conclusions and Policy Suggestions on Reciprocity}

The practice of reciprocity or mutual buying agreements cannot be adequately analyzed without reference to the prices at which the transactions occur. There are legitimate business reasons that explain the practice of reciprocity by firms without market power. Firms may use each other's products because each is an efficient producer who sells at prices below those quoted by other firms. Firms may enter into these agreements and reduce their costs of search or their advertising costs or the costs of uncertainty. The fact that reciprocity is often practiced by firms without market power is strong evidence that there are legitimate reasons for the practice. Firms with market power will also engage in reciprocity for the same reasons. It is not sufficient to examine the market shares of the firms involved to determine the legitimacy of the practice.

Coercion to induce purchase is only necessary when the buyer-seller is selling a good at a higher price or lower quality than is available from other firms. ${ }^{52}$ In an examination of conditions in which the buyer had purchasing power in the market for an intermediate good, no convincing case was found in which the firm would not use the power directly to secure the intermediate product at the lowest possible price rather than indirectly via reciprocity. If the supplier-buyer is only earning a competitive rate of return, then the buyer-seller with market power cannot impose additional costs on him by requiring him to purchase some intermediate good at a price above those of alternative sources. He would simply go out of business, which is not in the interests of the dominant firm.

When there are only a few producers of a product used by their suppliers, one or more of these producers may use reciprocity as a means of price cutting that cannot be so easily matched by rivals. Finally, where both firms have a dominant market position, reciprocity may occur in the absence of alternative buyers and sellers, but there is no rationale that supports the view that such an agreement by itself will reinforce the dominant position of each firm and make entry more difficult into either market.

The inevitable conclusion is that reciprocity is not a phenomenon that depends on market power, and the removal of market concentration would not eliminate the factors that give rise to reciprocity. At best, reciprocity can secure sales for the firm

\footnotetext{
${ }^{02}$ It may be worth noting that reciprocity involving purchases at higher prices than are available from other sources is widely done by governments at the state and local levels. Often these government units accept bids from local enterprises, as long as they do not exceed bids from nonlocal firms by more than some percentage like 10\%. The local citizens "buy" government services via taxes, and the government uses the tax money to buy its needs locally.
} 
at equal prices. Competitors are foreclosed from sales at equal prices, but this will not affect competition as all firms can practice reciprocity. Given legitimate business reasons for doing so, there will be many such arrangements among firms that are mutual suppliers. Any successful selling technique will increase a firm's sales at the expense of rivals (assuming no corresponding increase in demand), but this is the very essence of competitive rivalry. These agreements will not lessen competition and, therefore, are not a proper concern of antitrust. 